\title{
Szczęście w strukturze normatywności (część II - Szczęście)
}

\author{
Andrzej Niemczuk \\ https://orcid.org/0000-0002-8886-4254
}

Etyka przedkantowska była zbudowana na schemacie, według którego w działaniu praktycznym człowiek powinien robić to, co go uszczęśliwia. Spór dotyczył tylko natury szczęścia i natury człowieka. Kantowskie zakwestionowanie uzasadnienia powinności za pomocą odwołań do szczęścia oraz teoria błędu naturalistycznego spowodowały, że współczesne teorie normatywności (oprócz jedynie utylitaryzmu) opierają się na zasadzie separacji normatywności od szczęścia, co w konsekwencji prowadzi do wyrugowania problematyki szczęścia z filozofii praktycznej. Punktem wyjścia artykułu jest argumentacja na rzecz następujących twierdzeń krytycznych: (a) bez odwołania do szczęścia normatywność nie może być zadowalająco ani wyjaśniona, ani uzasadniona; (b) utylitarystyczna koncepcja szczęścia nie nadaje się do uzasadnienia normatywności. Pierwszą część artykułu kończy zarys struktury normatywności wraz z propozycją odpowiedzi na pytanie: dlaczego powinienem respektować normatywność? Druga część artykułu prezentuje taką koncepcję szczęścia, która normatywności nie wyklucza, lecz stanowi dla niej niezbędne uzasadnienie. Po zidentyfikowaniu desygnatu pojęcia szczęścia scharakteryzowany zostaje jego rdzeń w postaci eutymii, pojmowanej jako stabilne zadowolenie z faktu bycia podmiotem. Całość jest zakończona argumentacją pokazującą komplementarność szczęścia i normatywności.

Słowa kluczowe: normatywność, szczęście, podmiot praktyczny, filozofia praktyczna

ANDRZEJ NIEMCZUK, doktor habilitowany, prof. UR, Instytut Filozofii, Wydział Socjologiczno-Historyczny (Kolegium Humanistyczne), Uniwersytet Rzeszowski; adres do korespondencji: al. T. Rejtana 16 C, 35-959 Rzeszów; e-mail: aniemczuk@ur.edu.pl 


\section{Identyfikacja szczęścia w filozofii praktycznej}

Rzadko zauważany jest pewien fundamentalny paradoks, na którym opiera się dojrzała idea filozofii praktycznej. Dojrzałość idea ta uzyskuje wówczas, gdy namysł nad nią zawiera w sobie niesprzeczne odpowiedzi na pytania o jej podstawowe warunki możliwości, oraz o jej ostateczne cele. Jeśli ktoś pojmuje samą praktykę w sposób naiwny, czyli jako sferę aktywności pewnego gatunku bytów realnych (zwanych ludźmi) - bytów podlegających prawom przyrody lub prawom obowiązującym w dziedzinie bytu realnego - to jego idea filozofii praktycznej nie może być dojrzała. Wówczas bowiem podstawowe i konieczne kategorie filozofii praktycznej, takie jak wolność, wartość (dobro) czy działanie praktyczne, nie mogą uzyskać zadowalającej treści, gdyż „w ostatecznej instancji” muszą być zredukowane do faktów i procesów przyrodniczych, a tym samym pozostać przedmiotem wiedzy teoretycznej. Dojrzała zatem postać idei filozofii praktycznej, to taka, która opiera się na świadomości, że praktyka jest procesem kategorialnie odmiennym od procesów przyrodniczych, gdyż (a) jest inicjowana przez niesprowadzalną do faktów wolność oraz (b) zmierza do niesprowadzalnych do faktów wartości. Te dwa konieczne krańce praktyki wymuszają też wniosek, że może być ona prowadzona nie przez dowolny byt realny, lecz wyłącznie przez autonomiczny podmiot. Wolność, wartości i autonomiczna podmiotowość są więc niezbędnymi warunkami dojrzałej idei filozofii praktycznej, a jej zadaniem jest szczegółowe wytłumaczenie tych warunków i wyjaśnienie ich praktycznego współfunkcjonowania.

Paradoks, o którym chcę nadmienić, polega zaś na tym, że praktyka jako centralny przedmiot filozofii praktycznej, może być poznawana empirycznie o tyle tylko, o ile uprzednio w doświadczanej sferze przyrodniczej zidentyfikuje się ją i wyróżni za pomocą pojęć z gruntu nieempirycznych - takich jak wolność, wartości czy podmiot. Oznacza to, że ten sam empiryczny proces, jeśli jest interpretowany przez pryzmat wymienionych pojęć, to okazuje się praktyką, a jeżeli realne odniesienie tych pojęć zakwestionujemy, to okaże się przyczynowo-skutkowym procesem przyrodniczym. Kwestia ta jest o tyle kłopotliwa, że realnego istnienia wolności, wartości oraz autonomicznych podmiotów nie da się wykazać empirycznie. A skoro tak, to również zawisła od tych realności identyfikacja działań praktycznych nie może swej trafności oprzeć na kryterium empirycznym, lecz musi być konstrukcją myślową ocenianą wedle jej spójności z innymi pojęciami 
określającymi dziedzinę praktyki. Jeśli więc ktoś wymagałby od pojęć filozoficznych empirycznej legitymizacji, to cała filozofia praktyczna musiałaby być uznana za fikcję.

O tym nieempirycznym statusie filozofii praktycznej - polegającym na tym, że trzeba założyć istnienie wolnej praktyki, żeby móc ją wyjaśniać ${ }^{1}$ - wspominam dlatego, że taki sam status, siłą rzeczy, ma pojęcie szczęścia. Pojęcia tego nie ani nie uzyskuje się na podstawie doświadczenia, ani nie tworzy się po to, by jakiś fragment doświadczenia nazwać. W dziedzinie pozytywnych doznań empirycznych występują inne pojęcia, którymi - mniej lub bardziej dokładnie - doznania te określamy, takie jak: przyjemność, rozkosz, radość, zadowolenie, błogość, euforia, ekstaza ${ }^{2}$, zachwyt itp. Te pojęcia empiryczne od pojęcia szczęścia różnią się tym, że (1) ich desygnat jest psychiczną reakcją na coś, co zawsze jest wyraźnie zlokalizowanym w czasie i przestrzeni fragmentem doświadczenia - prawie zawsze fragment ten jest jednorazowym zdarzeniem lub jakimś ściśle określonym obiektem; (2) odnoszą się do przeżyć psychicznych, które do swojego zaistnienia nie potrzebują refleksyjnego namysłu - są powodowane bezpośrednio przez obiektywne zdarzenia, bez koniecznego pośrednictwa autorefleksji. Pojęciem „szczęścia” natomiast określa się (od czasów Sokratesa i Arystotelesa) uczuciową reakcję podmiotu na pozytywną ocenę całości własnego życia ${ }^{3}$. Adekwatne użycie pojęcia szczęścia przez podmiot zakłada więc: (1) ocenę tego, co on w kontakcie ze światem przeżywa oraz (2) wzięcie w tej ocenie pod uwagę całości życia. Jeśli więc szczęście nie jest jednym z wielu pozytywnych uczuć wywołanym przez jeden w wielu doświadczanych obiektów, to oznacza to, że (1) wobec uczuć ma ono charakter metapoziomu (można by rzec - jest metauczuciem) oraz (2) jako że musi się opierać na bilansie (przeglądzie i ocenie) wszystkich przeżyć, to bezpośrednim przedmiotem jego odniesienia nie są poszczególne obiekty świata zewnętrznego, lecz właśnie wspomniany bilans, którego można dokonać tylko mocą autorefleksji. Już te dwie cechy szczęścia ujawniają, że jego pojęcie nie należy do pojęć psychologii empirycznej, lecz wobec faktów psychicznych stanowi ono nową, wyższą

\footnotetext{
${ }^{1}$ Naturę praktyki dokładniej analizowałem w: „Kolista struktura praktyki. Rozważania metapraktyczne”, w: Andrzej Niemczuk, Filozofia praktyczna. Studia i szkice (Lublin: Wydawnictwo UMCS, 2016), 125-147.

${ }^{2}$ W dzisiejszym, a nie w dawnym, źródłowym znaczeniu (jako „stanie na zewnątrz siebie”).

${ }^{3}$ Pomijam tu zupełnie znaczenie „szczęścia” jako fortuny, czyli jako sprzyjającego losu lub pomyślnego zbiegu okoliczności. Fortuna nie zależy od działań podmiotu - leży więc poza zainteresowaniami etyki.
} 
kategorię, którą można określić jako egzystencjalną: stosowanie tego pojęcia wymaga bowiem refleksyjnego namysłu samoświadomości nad uczuciową zawartością psychiki skonfrontowanej z faktem istnienia. Ściśle biorąc, ten rodzaj zadowolenia, który jest szczęściem, stanowi reakcję na treść autorefleksji - co w konsekwencji oznacza, że szczęście jest dostępne tylko bytom samoświadomym. Jeśli pozytywne doznania, jakie czerpie organizm na podstawie kontaktów z obiektami świata nazwiemy przyjemnościami, to szczęście trzeba odróżnić od przyjemności. Łączy je bowiem tylko pozytywność doznaniowa, oddzielają je zaś od siebie następujące cechy szczęścia, których przyjemności nie posiadają: (1) całość życia jako podstawa przedmiotowa; (2) niezbędność autorefleksji zarówno dla przedstawienia sobie owej całości życia, jak i dla dokonania jej bilansu; (3) (w związku z powyższym) reagowanie zadowoleniem na treść autorefleksji, nie zaś na treść wrażeń płynących ze świata; (4) względna trwałość utrzymująca się niejako ponad zmiennością stanów psychicznych; (5) i w końcu, obecność oceny tego, co przeżywane (odczuwanie przyjemności nie zależy od jej oceny, szczęście zaś jest zadowoleniem z rezultatu oceny - co jest efektem bezrefleksyjności przyjemności i refleksyjności szczęścia).

Wymiary artykułu nie pozwalają na rozwijanie ani analiz językowych precyzujących znaczenie słowa „szczęście”, ani na szczegółową charakterystykę fenomenologiczną odróżniającą szczęście od innych stanów podmiotu. Ponieważ jednak zarówno język naturalny, jak i to, co się jawi, nie są wolne od różnego rodzaju przypadkowych uwarunkowań, to równie dopuszczalna (i zarazem krótsza) wydaje się procedura identyfikowania szczęścia za pomocą argumentacyjnego konstruowania jego pojęcia, uwzględniającego jego znaczenia obecne w filozofii.

Sposób identyfikowania natury szczęścia, który traktuje je jako zaistniały już i pasywnie odczuwany fakt (nazwę go sposobem psychologicznym), pomimo tego, że kierowany jest naturalną i zrozumiałą chęcią odpowiedzi na pytanie „co to jest?”, ma duże trudności z określeniem pojęcia szczęścia, jak również z uchwyceniem i opisem treści uczuć, które by się na szczęście składały. Trudności te są analogiczne do tych, które występują przy psychologicznych próbach odpowiedzi na pytanie „czym jest ja?” - pomimo wszak, że ludzie mają poczucie własnego „ja”, to jednak jest ono na tyle niejasne, że badawcza koncentracja na jego treści (czy to koncentracja empiryczna, czy pojęciowo-analityczna) powoduje raczej większą problematyczność tej treści niż jej precyzyjną identyfikację. Dzieje się tak dlatego - jak pokazują odnośne analizy np. D. Hume’a, I. Kanta czy E. Husserla - 
że „ja” nie jest dane doświadczeniu w postaci przedmiotowej treści, lecz w niejasny sposób koniecznie towarzyszy doświadczaniu wszelkich treści. Znaczy to, że pojęcie ,ja" jest wprawdzie praktycznie niezbędnym pojęciem potocznym, ale przy teoretycznych ustaleniach dotyczących jego natury niewiele można skorzystać z psychologicznej empirii - raczej pojęcie to trzeba najpierw teoretycznie skonstruować, żeby następnie różne doświadczenia móc za jego pomocą objaśniać. $\mathrm{Z}$ taką samą sytuacją mamy do czynienia $\mathrm{w}$ przypadku pojęcia szczęścia. Ludzie mówią, że dążą do szczęścia i że je w mniejszym lub większym stopniu osiągają, ale zarówno oni sami, jak i empirycznie zorientowani teoretycy mają ogromne trudności z odpowiedzią na pytania typu „co to jest szczęście?” lub „jaka jest treść w doświadczaniu szczęścia?” Trudności te biorą się z faktu, że treściowe składniki szczęścia w przypadku różnych podmiotów mogą, a nawet muszą, się częściowo różnić, nie wyklucza to jednak - jak zresztą w odniesieniu do każdego pojęcia ustalenia identycznych cech formalnych, które muszą przysługiwać X-owi, żeby mógł on należeć do zakresu pojęcia szczęścia. Tak zatem, jak G. E. Moore w odniesieniu do kwestii dobra rozróżnił dwa odmienne pytania ${ }^{4}$, tak samo wobec problemu szczęścia trzeba odróżnić formalne pytanie „co to jest szczęście?” od pytania treściowego „jakich treści trzeba doświadczać aby być szczęśliwym?” Na pierwsze z tych pytań jest możliwa odpowiedź uniwersalna, odpowiedź na drugie należy zaś relatywizować do indywidualnych podmiotów (dlatego, że fakt różnic podmiotowych musi pociągać za sobą częściowe różnice w zestawach uszczęśliwiających treści). Jako że mój wywód ma charakter teoretyczno-filozoficzny, to jasne jest, że priorytetowe jest w nim pierwsze z tych pytań - drugie pozostaje raczej w zakresie kompetencji coachingu i doradztwa filozoficznego.

Jak już wspomniałem, trudne jest ustalanie formalnych (uniwersalnych) cech szczęścia sposobem psychologicznym, gdyż koncentrując się na doświadczanych treściach sposób ten napotyka wśród nich duże zróżnicowanie osobnicze, w wyniku czego powstaje mylne wrażenie, że treść pojęcia szczęścia jest skrajnie relatywna. Tymczasem w strukturze ludzkiego działania priorytetowa wydaje się praktyczna funkcja idei szczęścia, nie zaś pozostawanie w pasywnym jego doświadczaniu - niewielu ludzi spędza czas na kontemplacyjnym delektowaniu się własnym szczęściem, wszyscy zaś całymi dniami do niego dążą. Chcę przez to po-

${ }^{4}$ Chodzi o pytania: „co to jest dobro?” i „co jest dobre?”. 
wiedzieć, że pomimo, iż „szczęście” nazywa niewątpliwie pewien rodzaj doznawania, to jednak - z racji tego, że sednem podmiotowości ludzkiej jest samowiedna aktywność wolności - idea szczęścia najwyraźniej przejawia się w postaci podstawowego projektu praktycznego: jest ona ideą, która, najogólniej mówiąc, określa cele w autonomicznym organizowaniu życia praktycznego. Znaczy to, że pojęcie szczęścia niezbędne jest przede wszystkim do tego, by móc zrozumieć teleologiczną naturę ludzkiej praxis (oraz do tego, rzecz jasna, by własną praxis świadomie „prowadzič"), rozmywa się zaś ono zarówno wtedy, gdy chcemy zdać raport z doświadczenia jego desygnatu, jak i wówczas, gdy usiłujemy je zidentyfikować w psychicznych stanach innych ludzi, abstrahując od ich teleologicznej aktywności.

To wszystko nie znaczy wprawdzie, że niemożliwe jest zidentyfikowanie szczęścia na podstawie samego pasywnego odczuwania, znaczy tylko, że zwrócenie uwagi na praktyczny aspekt idei szczęścia jest korzystniejsze dla teorii szczęścia - pozwala bowiem (1) sformułować na jego temat więcej twierdzeń, (2) nadać argumentacji bardziej intersubiektywny charakter (nie poprzestający jedynie na odwoływaniu się do indywidualnej introspekcji), a także (3) zauważyć i wyeksplikować te cechy szczęścia (ważne dla filozofii praktycznej), które są niedostrzegalne w samym pasywnym jego odczuwaniu. Na podstawie tego odczuwania bowiem niewiele można o szczęściu stwierdzić ponad to, że jest ono rozpoznawanym za pomocą autorefleksji takim stanem zadowolenia, w którym wygasają wszystkie motywy do jego zmiany (poza ewentualnym motywem do jego maksymalizowania, o ile nie jest maksymalny) - ale nawet stwierdzenie tegoż wymaga, by tak rzec, niestandardowych kompetencji zarówno do autoanalizy, jak i w zakresie konceptualizacji ludzkiej duchowości. I chociaż doświadczane zalążki lub namiastki takich stanów są najpewniej treściowym źródłem dla kształtowania się indywidualnych projektów szczęścia, to jednak nie wystarczają one do objaśnienia dojrzałej idei szczęścia, która w pełni formuje się i jest korygowana dopiero w samowiednym działaniu praktycznym.

Uwzględniając pasywno-doznaniowy charakter szczęścia, jego identyfikację w myśleniu i dążeniu praktycznym można zacząć od ogólnego stwierdzenia, iż jest ono projektowanym przez działający podmiot zadowoleniem, które chce on osiągnąć $i$ utrwalić w swoim odczuwaniu, będącym reakcją na świadomą ocenę całości 
jego życia ${ }^{5}$ Konieczność posiadania tego typu projektu wypływa z faktu, że człowiek jest bytem samoświadomym - to bowiem dla jego życia i działania oznacza, że podejmując różne przedsięwzięcia, nie może podejmować ich bez powodu. Pojęcie powodu - dla uniknięcia nieporozumień - trzeba objaśnić szerzej. Otóż ludzka dynamika może mieć trzy różne rodzaje powodów. Po pierwsze, przyczyny (fizyczne i biologiczne), po drugie, motywy (psychiczne pragnienia lub obawy), po trzecie, racje praktyczne (sądy praktyczne racjonalnie uzasadnione). Pierwsze z nich zazwyczaj są nieuświadomione, drugie są świadome, ale nie należą do porządku uzasadnienia (jako psychiczne fakty, nie są one ani uzasadnione, ani uzasadniające) - tylko trzecie, czy li racje, są powodami racjonalnymi, tzn. każda pojedyncza racja jest zarówno uzasadniona (przez inne racje), jak i uzasadniająca (albo dla kolejnych racji, albo dla działań). Ze względu na relację do świadomości wymienione rodzaje powodów przedstawiają się następująco: przyczyny są nieuświadomione, motywy są świadome (mogą nimi być uświadomione przyczyny), ale nie racjonalne, racje praktyczne zaś - czyli sądy praktyczne, które uzyskuje się poprzez poddanie motywów refleksyjnemu testowi racjonalności - są składnikami racjonalności i samowiedzy (mogą nimi być uzasadnione motywy). Samowiedza z racjonalnością praktyczną są (wedle takiego ujęcia) połączone w tym sensie, iż przekształcanie się faktycznej samoświadomości w osiąganą samowiedzę polega na nadawaniu tej pierwszej racjonalnego, logiczno-systematycznego charakteru. Znaczy to, że nabywanie samowiedzy nie może ominąć przyswajania racjonalności. Szczególnie racjonalność praktyczna, jako że powstaje w odpowiedzi na refleksyjne pytania o uzasadnienie dążeń, jest w istocie wytworem i składnikiem samowiedzy ${ }^{6}$.

Ważne jest to, iżby zauważyć, że ludzkie działanie ma charakter podmiotowy, czyli jest działaniem wolnym, tylko wtedy, gdy jest powodowane przez racje praktyczne. Dopóki zaś jego dynamiką rządzą przyczyny bądź motywy, dopóty: (a) dynamika ta nie jest jego działaniem; (b) on nie jest podmiotem; (c) jako że jego dynamika podlega uwarunkowaniom przyczynowym, to nie jest ona wolnym

${ }^{5}$ Łatwo zauważyć, że ta formuła jest modyfikacją Arystotelesowskiego, formalnego określenia, wedle którego szczęście jest tym, czego wszyscy pożądają dla niego samego. Por. Arystoteles, Etyka nikomachejska, tłum. Daniela Gromska (Warszawa: PWN, 2012), 87-88, 1097a-1097b.

${ }^{6} \mathrm{O}$ racjonalności praktycznej szerzej pisałem w: „Practical Rationality - its Nature and Operation", Studia Humana 8, nr 2 (2019): 55-68. 
sprawstwem. Gdy więc stwierdzam, że fakt samoświadomości - która w naturalnej dynamice życia przekształca się w samowiedzę - wymusza posiadanie powodu dla wszystkich praktycznych przedsięwzięć, to mam na myśli właśnie i tylko racje praktyczne. Inne powody degradują bowiem działanie do statusu procesu przyrodniczego.

Pomijając na razie normatywny charakter racji praktycznych, o ich szczegółowych treściach trzeba powiedzieć, iż pochodzą one od zróżnicowanej określoności zdarzeń i obiektów świata realnego. Jeśli warto się gimnastykować lub spełniać obietnice, to treści racji stojących za tymi działaniami różnią się od siebie tym, czym różni się gimnastyka od dotrzymywania obietnic. Gdyby jednak podmiot poprzestał w swoim działaniu tylko na tego typu racjach szczegółowych, to po pierwsze, niewiadome byłoby (również dla niego samego), dlaczego i po co owe racje respektuje (dlaczego one są dla niego racjami), a z tego powodu, po drugie, $z$ braku jednoczącej syntezy, jego życie rozpadłoby się na wielość niezwiązanych ze sobą działań, co postawiłoby pod znakiem zapytania tożsamość ich sprawcy. Co więcej, ograniczenie kierowania działaniami wyłącznie do racji poszczególnych pozbawiałoby podmiot, z braku zwierzchniego kryterium, możliwości wyboru między nimi. Znaczy to, że tak jak teoretyczne ustalanie autorstwa działań każe różne działania przypisywać jednemu ja, tak samo praktyczne podejmowanie różnych działan - jeśli mają być one wolne - wymaga od ich podmiotu posiadania jednej, rzec by można, metaracji praktycznej, która byłaby odpowiedzią na pytanie, dlaczego i po co on różne racje szczegółowe akceptuje oraz spełnia nakazywane przez nie działania. Innymi słowy, jeśli podmiot działania jest samowiedną jednością, to musi mieć też jedną metarację dla swoich różnych racjonalnych działań - musi dysponować odpowiedzią na pytanie, po co podejmuje wszystkie konkretne działania. Brak takiej odpowiedzi znaczyłby, że podmiot nie wie, po co działa - to zaś kwestionowałoby wolność oraz faktyczne autorstwo jego działań. Otóż twierdzę, że kiedy samowiedny podmiot zadaje sobie pytanie (lub inni mu je zadają), dlaczego i po co ponosi trud wszelkich podejmowanych działań, to jakkolwiek swój faktyczny lub spodziewany „zysk” z owych działań by nazwał, w odpowiedzi tej musi wyjść na jaw idea szczęścia. Nie można bowiem działać świadomie i racjonalnie, jeżeli działania nie umieści się myślowo wewnątrz horyzontu jakiegoś ostatecznego zadowolenia, które wobec wszystkich zamierzonych działań stanowi zarówno ich primus motor, jak i projektowany ich owoc. 
Ostateczność tego zadowolenia polega, oczywiście, na tym, że będąc sumarycznym efektem wszelkich działań, samo nie jest instrumentem do niczego innego i wobec tego nie można wobec niego postawić sensownie pytania „po co?” (tę cechę szczęścia Arystoteles nazywał samowystarczalnością). Ten horyzont zadowolenia, którym opasane pozostaje wszelkie świadomie prowadzone działanie, jest właśnie szczęściem.

Podsumowując, jedność samoświadomego ja wymaga, żeby zróżnicowana wielość jego działań miała u swoich podstaw jednoczący ją motyw, którego treść jest zarazem projektem sumarycznego zadowolenia jako spodziewanego efektu tych działań. Człowiekowi działającemu bez takiego motywu nie można bowiem przypisać atrybutów podmiotowości, takich jak samowiedza, racjonalność i wolność. Ale wynika z tego, że w podmiocie posiadającym wymienione atrybuty musi także być obecny - w jakiejś modalności - atrybut szczęścia. Modalności tego atrybutu są dwie: (a) realność, czyli pewien stopień szczęścia jako odczuwany fakt, który towarzyszy istnieniu podmiotu; (b) możliwość, która w perspektywie praktycznej przybiera postać podmiotowego dążenia do szczęścia (a ściślej: dążenia do maksymalizacji posiadanego stopnia szczęścia, do odzyskiwania szczęścia chwilowo utraconego oraz do zabezpieczania jego trwałości w rzadkich przypadkach osiągnięcia jego pełni). Obecność pierwszej modalności musimy przyjąć dlatego, że bez niej nie potrafimy odpowiedzieć na pytanie, dlaczego wolne podmioty kontynuują swoje istnienie. Obecność modalności drugiej stanowi z kolei odpowiedź na pytanie, dlaczego podmioty kontynuują działanie. A skoro, jak się okazuje, nie można być podmiotem bez tych dwóch modalności, toteż uzasadnione jest twierdzenie, że składają się one na egzystencjał szczęścia, czyli na taki atrybut podmiotu, który jest nieodłączny od podmiotowego istnienia.

\section{Eutymia jako rdzeń szczęścia}

Analiza wszystkich kwestii szczegółowych, jakie gromadzą się wokół problemu szczęścia, nie jest w artykule możliwa. Zgodnie z przewodnim wątkiem artykułu dalszy wywód ograniczę zatem do wyeksponowania tych aspektów szczęścia, która mają ścisły związek z normatywnością. W objaśnianiu natury szczęścia największą trudność sprawia zazwyczaj empiryczna wielość i relatywność jego składników oraz śledzenie między nimi wzajemnych związków. Jeśli teoretyk wda 
się w ich analizę, to grozi mu utonięcie w bezmiarze tych szczęściogennych, ale zarazem nieintersubiektywnych czynników. Tymczasem dla filozoficznej teorii szczęścia owa wielość jego składników - wynikająca po prostu z faktu różnic między konkretnymi podmiotami - nie jest wcale najważniejsza, a jej katalogowanie nie wystarczy do odpowiedzi na pytanie, czym ten rodzaj zadowolenia, który jest szczęściem, różni się od innych rodzajów zadowolenia. Na pytanie to łatwiej jest znaleźć odpowiedź, jeśli uwagę skupi się na najbardziej ogólnych aspektach szczęściach, czyli takich, które (a) są związane z jednością i integralnością podmiotu (z jego „istotą”) i dlatego (b) są powtarzalne w każdym podmiocie - szczęście wszak do wielości innych zadowoleń ma się tak samo, jak podmiot do wielości swoich składników i funkcji (każdy podmiot ma tylko jedno szczęście, gdyż sam jest jeden). Można wręcz stwierdzić, że pojęcie szczęścia jest po to, by w myśleniu podmiotu o samym sobie mogło zjednoczyć i zbilansować całość jego zadowoleń i przykrości, zarówno zaistniałych, jak i projektowanych - i żeby, jako taka jedność, mogło stanowić kryterium dla harmonizowania rozmaitych celów ${ }^{7}$.

$\mathrm{Z}$ racji tego, że podmiot jest bytem samoświadomym i samowiednym, jednym $\mathrm{z}$ obiektów, który on nie tylko może, ale wręcz musi uwzględniać w swoim bilansie życia, jest on sam - i spośród obiektów wewnątrzświatowych jest to dla niego bodaj jedyny obiekt niewymienialny. Ponieważ w całości dostępnego mu spectrum przedmiotów jedynie on sam jest dla siebie konkretem niewymienialnym (poza przedmiotami, które nie są konkretami, takimi jak np. prawa świata realnego), toteż zadowolenie $\mathrm{z}$ siebie samego ma w jego szczęściu udział szczególny. Wyjątkowość siebie samego jako obiektu zadowolenia polega mianowicie na tym, że: (a) obiekt taki musi wystąpić w szczęściu każdego przedmiotu (jest - by tak rzec - jednostkowo uniwersalny); (b) nie można go wymienić na inny, lecz tylko w wąskich granicach zmodyfikować; (c) cała jego historia (od początków świadomego życia aż po domniemywalny i podlegający planowaniu horyzont jego przyszłości), musi być uwzględniana w szczęściodajnym bilansie - będąc

\footnotetext{
${ }^{7} \mathrm{Na}$ harmonizowanie wielości celów jako podstawową (wręcz jedyną) funkcję pojęcia szczęścia z naciskiem wskazuje np. Nicholas White. Por. Filozofia szczęścia. Od Platona do Skinnera, tlum. Marek Chojnacki (Kraków: Wydawnictwo WAM, 2008), 149-151.
} 
wszak zadowoleniem także z diachronicznej całości życia, szczęście musi obejmować zmienność warunków i efektów czasowego funkcjonowania podmiotu ${ }^{8}$.

Siebie samego można wprawdzie oceniać (i być z siebie odpowiednio zadowolonym) pod różnymi względami - właściwie pod względem każdej spełnianej czynności i funkcji. Tego typu samooceny nie są jednak dla szczęścia ani zbyt efektywne, ani zbyt wiążące, ponieważ do bycia dobrym w poszczególnych dziedzinach podmiot może po prostu nie pretendować, albo, po próbach nieudanych, bez większej szkody może zmienić sferę swej działalności. Nikogo nie unieszczęśliwia fakt, że nie jest, dajmy na to, dobrym bokserem, jeżeli chce być dobrym poetą - ale nawet swoje nieudane próby poetyckie może $\mathrm{z}$ uśmiechem porzucić na rzecz innych celów. Rzecz natomiast w tym, że nie może z uśmiechem porzucić bycia podmiotem, zaś całość swojego zadowolenia czerpać na przykład z sukcesów w kolekcjonerstwie znaczków pocztowych. Gdybyśmy nawet znaleźli takiego człowieka, to jego zadowolenia nie można byłoby nazwać szczęściem.

Z powodu owej wyróżnionej pozycji siebie samego, trzeba wśród wszystkich składników szczęścia rozróżnić zadowolenie z własnej podmiotowości oraz całą resztę zadowoleń (i przykrości), które, z powodu ich możliwej zastępowalności, można nazwać akcydentalnymi (i których obiekty, w ramach tej akcydentalności, można dalej klasyfikować np. na własne osiągnięcia, innych ludzi i warunki oraz zdarzenia losowe). Ponieważ klasa zadowoleń akcydentalnych ma dla problemu normatywności znaczenie drugorzędne, to szczegółowa jej analiza nie jest tu konieczna, trzeba natomiast rozpatrzyć dokładniej stosunek do samego siebie, który zarówno dla szczęścia, jak i dla normatywności jest wręcz „punktem Archimedesowym”. Patrząc od strony ontogenezy człowieka, pierwszym materiałem dla kształtowania się idei szczęścia wydają się jego czynniki akcydentalne - na „szczęśliwe dzieciństwo" składają się wszak takie elementy, jak tzw. minimum socjalne (brak skrajnej biedy), poczucie bezpieczeństwa, grono przyjaznych osób i trochę

\footnotetext{
${ }^{8}$ Można nawet stwierdzić, że pewnego rodzaju przezwyciężanie czasu stanowi o istocie szczęścia. Gdyby ludzkie życie nie było skazane na czasową rozciągłość, a co za tym idzie, zmienność, to idea szczęścia do organizowania życia nie byłaby wcale potrzebna - wystarczyłoby zapewnienie sobie „przyjemnych chwil". Tymczasem dlatego właśnie, że do natury przyjemności należy ich życiowa przemijalność (niemożliwość trwania przez całe życie) oraz określona przez psychologiczne reguły dynamika (przyjemność ponad miarę „przedłużana” staje się przykrością), konieczne jest selektywne „gospodarowanie” przyjemnościami w celu budowania i zabezpieczania zadowolenia życiowo trwałego, którym jest szczęście. Czasowość też wymusza, niezbędną do budowania szczęścia, cnotę rozsądku praktycznego (fronesis) lub roztropności (prudentia), która w życiu bezczasowym także byłaby zbędna.
} 
radości z codziennych zabaw. Ale nawet już w dzieciństwie szczęściodajny charakter wymienionych elementów możliwy jest dzięki czemuś głębszemu, co można określić jako wewnętrzna równowaga dziecka (spokój, beztroska?), zapewniana mu przez odpowiedni stosunek do niego jego bezpośrednich opiekunów (rodziców). Ponieważ dziecko nie posiada jeszcze wykształconej i stabilnej podmiotowości, toteż jego stosunek do samego siebie jest kształtowany przez innych ludzi - przez rodziców i najbliższych wychowawców. Niemniej, właśnie ten stosunek - jego efekt w postaci wewnętrznego spokoju - jest niezbędnym warunkiem cieszenia się obiektami świata zewnętrznego. Krótko mówiąc, pomimo że podmiot powstający w dziecku pochodzi w znacznej mierze z zewnątrz (od innych), w związku z czym dziecięca samowiedza jest jeszcze niewyraźna i rozmyta, to jednak od samoocennych komponentów tej samowiedzy zależy zadowolenie dziecka z przeżywanego świata. Natomiast wraz z wykształcaniem się dojrzałej i stabilnej podmiotowości u człowieka dorosłego punkt ciężkości składników szczęścia przesuwa się z czynników akcydentalnych w stronę zadowolenia z samego siebie. Można nawet stwierdzić, że podmiot dojrzały odznacza się samowiedzą o tym, że zadowolenie z samego siebie jest dla niego ważniejsze niż zadowolenie z jakiegokolwiek obiektu zewnętrznego. Tylko bowiem dzięki takiej samowiedzy podmiot może być autonomiczny w swej samosterowności - inaczej bowiem atrakcje różnych światowych pokus i tendencje konformistyczne wygrywałyby w nim permanentnie $\mathrm{z}$ jego samostanowieniem.

Zadowolenie z siebie, o jakim tu mowa, jest wprawdzie bliskie Arystotelesowskiej eudajmonii (zadowoleniu płynącemu z własnej doskonałości, polegającej na działaniu bezbłędnie rozumnym), ale najbliższe jest chyba Demokrytejskiej eutymii. O tej drugiej bowiem (tłumaczonej jako „pogoda ducha”, „spokój ducha”, „harmonia duszy”, „równowaga wewnętrzna”, a nawet „spokój serca” lub „posłuszeństwo serca wobec rozumu”) można powiedzieć, że polega ona na zgodności niższych funkcji duszy, takich jak uczucia i powodowane przez nie działania, z najwyższą funkcją duszy, czyli z rozumem - dlatego jest ona harmonią (brakiem rozłamu) wewnątrz ludzkiej subiektywności i tylko jej towarzyszy wewnętrzny spokój. Wedle ujęcia proponowanego tutaj, zadowolenie z własnej podmiotowości należy objaśniać za pomocą pojęć, które tłumaczą strukturę podmiotu praktycznego. Najważniejsze zaś w tej strukturze (o czym była już mowa w III paragrafie części I artykułu) są takie jej elementy, jak wolność w postaci samodeterminacji oraz kierowanie się w działaniu racjami (racjonalność praktyczna) opartymi 
ostatecznie na pradecyzji. Ponieważ ta ostatnia oznacza afirmację istnienia siebie jako podmiotu, to pociąga za sobą również afirmację atrybutów podmiotowości. Prowadzi to do wniosku, że o ile ktoś jest samowiednym podmiotem sprawstwa, to dysponuje już afirmatywnym stosunkiem do własnych podmiotowych atrybutów. W tym kontekście zadowolenie $\mathrm{z}$ własnej podmiotowości należy rozumieć jako zadowolenie $\mathrm{z}$ faktu, że prowadzone przez podmiot realne życie praktyczne wobec afirmowanej przez niego własnej autonomii i racjonalności praktycznej nie jest niezgodne, lecz stanowi ich konsekwentny przejaw i wierne świadectwo. Wówczas także zachodzi zgodność realnego działania z pierwotną wolą, która dla bycia podmiotem jest wręcz konstytutywna.

Owa zgodność działań podmiotu z jego wolą bycia podmiotem była w dziejach filozofii wielokrotnie i pod różnymi pojęciami przedstawiana jako najlepszy stan w życiu człowieka. Myślę, że na tym w istocie polegała wspomniana już Demokrytejska eutymia, zmuszony był ją uznać Kant pod postacią Selbstzufriedenheit, czyli jako zadowolenie z bycia rozumnym, a egzystencjaliści sławili ją pod mianem autentyczności. Nie od rzeczy będzie też zauważyć, że wymienione konceptualizacje najlepszego stanu człowieka (a z pewnymi zastrzeżeniami można do nich dołączyć jeszcze Arystotelesowską eudajmonię) powstawały w kontekstach myślenia, które nie dopuszczało istnienia wartości obiektywnych ani obiektywnej powinności. Ta zgodność zewnętrznego działania $\mathrm{z}$ wewnętrzną wolą bycia podmiotem we wszystkich wymienionych koncepcjach była pojmowana jako „mechanizm” samonagradzający się i samokarzący: jeśli człowiek osiąga i zachowuje ową zgodność, to uzyskuje też „nagrodę” w postaci wewnętrznego spokoju, jeżeli zaś panuje w nim niezgodność, to „karany” jest niepokojem, niezadowoleniem 
z siebie i poczuciem winy ${ }^{9}$. Bodaj najtrafniej i najobszerniej (acz w osobliwym języku) mówi o tym Heideggerowska teoria sumienia ${ }^{10}$, będąca niewątpliwie rozwinięciem Kierkegaardowskiego postulatu „wybierania siebie”. Choć nie wszystkie wymienione koncepcje mówiły wprost o szczęściu, to jednak przedstawianą zgodność wewnętrzną eksponowały jako stan najwyższy, który nadaje spójność normatywnym aktywnościom człowieka.

W moim ujęciu pojmowana w przedstawiony sposób eutymia stanowi rdzeń szczęścia - w tym mianowicie znaczeniu, że: (a) jest minimum zadowolenia, będącym wystarczającym motywem do kontynuowania życia; (b) jest warunkiem tego, by zadowolenia akcydentalne (z obiektów zewnętrznych) mogły posiadany stopień szczęścia wzmagać; (c) brak eutymii powoduje kompensowanie go za pomocą kompulsywnego gromadzenia zadowoleń akcydentalnych, których suma nigdy jednak nie wypełni tego braku do końca - w świetle podmiotowej samowiedzy rekompensata pozostanie niewystarczająca; (d) eutymia zapewnia szczęściu stabilną trwałość, dzięki czemu czyni je względnie odpornym na chwiejne przyrosty i ubytki w sferze zadowoleń akcydentalnych. Eutymia jest dla podmiotu swego rodzaju „twierdzą wewnętrzną”, której przykrości nie naruszają, a przyjemności nie są jej budulcem, lecz jedynie uzupełniającym ornamentem („wisienką na torcie”). Minimalne quantum przyjemności niezbędne do zadowolenia z życia jest bowiem zapewnione - jak trafnie podkreślał Epikur - przez, niezmącone rozterkami wewnętrznymi, świadome doznawanie „gołego” procesu życia.

Reasumując, ponieważ chcenie bycia wolnym podmiotem konstytuuje i podtrzymuje tożsamość podmiotu praktycznego, toteż własne empiryczne pogwałcanie tej równie własnej woli podmiotu musi, poprzez wewnętrzny rozłam, naruszać

\footnotetext{
${ }^{9}$ Ten ścisły, immanentny związek między odpowiednim działaniem (zwanym cnotą) a szczęściem trafnie ujął Baruch Spinoza (traktując go - niezbyt precyzyjnie - jako relację tożsamości): „Szczęśliwość nie jest nagrodą za cnotę, lecz cnotą samą, i cieszymy się nią nie dlatego, że powstrzymujemy żądzę, lecz odwrotnie, dlatego że się nią cieszymy, posiadamy możność powstrzymania żądz" [Etyka w porządku geometrycznym dowiedziona, tłum. Ignacy Myślicki (Warszawa: PWN, 1954), Cz. V, tw. 42, 1124]. Zdanie to, jak sądzę, należy interpretować następująco: ponieważ działanie zgodne z racjonalnością (cnota) automatycznie pociąga za sobą szczęście, toteż nasz zamysł dążenia do szczęścia uodparnia nas (w znacznej mierze) na pokusy pragnień nieracjonalnych; jeśli więc w działaniu praktycznym konsekwentnie „trzymamy się” tego (opartego na samowiedzy) zamysłu, to nasze szczęście jest jakby tożsame z naszym działaniem, bo następuje samoczynnie - nie trzeba nań oczekiwać jak na nagrodę od obcej nam instancji. Oczywiście, działanie nieracjonalne (niecnotliwe) w taki sam automatyczny sposób pozbawia nas szczęścia.
}

${ }^{10}$ Por. Martin Heidegger, Bycie i czas, tłum. Bogdan Baran (Warszawa: PWN, 1994), 380-423. 
jego zadowolenie z siebie, z kolei praktyczna konsekwencja, czyli empiryczna wierność swej pierwotnej woli - przeciwnie - zachowując spójność podmiotu, jest warunkiem trwania tego zadowolenia. Zadowolenie to jest zarazem „kamieniem węgielnym” całości szczęścia, gdyż jego brak uniemożliwia zastąpienie go przez zadowolenia płynące $\mathrm{z}$ zewnątrz (akcydentalne) oraz - w samowiedzy podmiotu - zakłóca spokojne i beztroskie delektowanie się nimi. Eutymia zatem, jeśli nawet nie jest całością szczęścia (wbrew Demokrytowi) ${ }^{11}$, to jednak stanowi najważniejszy i uniwersalny jego składnik. Wobec szczęścia jest ona warunkiem koniecznym w tym sensie, iż (a) już wystąpienie jej samej w podmiocie pozwala przypisać mu pewien stopień szczęścia, natomiast (b) zbiór zadowoleń podmiotu przy jej braku nie jest stanem szczęścia, lecz albo jego pozorami (przy niedostatecznej samowiedzy podmiotu), albo zbiorem przyjemności, które dopóty nie komponują się w stan szczęścia, dopóki brakuje im fundamentu w postaci eutymii. W Ewangelii - jeszcze jednym źródle idei eutymii - jest to wyrażone w sposób następujący: „,cóż bowiem za korzyść odniesie człowiek, choćby cały świat zyskał, a na swej duszy szkodę poniósł?” (Mateusz, 16.26).

\section{Szczęście jako podstawa i efekt normatywności}

Po przedstawionych zarysach struktury normatywności oraz struktury szczęścia pozostaje wykazać ścisły związek obu tych dziedzin. Otóż wobec faktu, że pojęcie tzw. wartości obiektywnych czy też obiektywnych powinności stanowi contradictio in adiecto (czyli wobec faktu, że bezwarunkowe normy nie istnieją), uzasadnienie normatywności musi opierać się na pierwotnym chceniu podmiotu, a treść tego chcenia jest określona przez ideę szczęścia. Mówiąc ogólnie, sferę normatywności podmiot powinien respektować dlatego, że ona jest warunkiem trwania jego szczęścia. Ponieważ jej treści pochodzą logicznie od jego chcenia bycia podmiotem, toteż (a) jej przestrzeganie daje mu zadowolenie z siebie jako podmiotu (czyli trwały rdzeń szczęścia w postaci eutymii), (b) zaś stosowanie się do

\footnotetext{
${ }^{11}$ Jeśli szczęście uznaje się za pierwszą rację działań wszystkich, to nie można eutymii uznać za całość szczęścia, gdyż dążenia do zadowoleń akcydentalnych nie znajdą wtedy racji, i będziemy musieli uznać je za nieracjonalne i zbędne (jak w radykalizmie stoickim).
} 
niej w życiu pozamoralnym - w którym chodzi o podwyższanie zadowolenia $\mathrm{z}$ istnienia - umożliwia maksymalizowanie szczęścia za pomocą właściwie dobranych jego składników akcydentalnych.

Dokładniej więc rzecz ujmując, w odniesieniu do sfery normatywnej idea szczęścia pełni funkcję racji w dwóch zasadniczych „miejscach” uzasadnienia tej sfery. Po pierwsze, szczęście - jako zadowolenie racjonalnego podmiotu z istnienia siebie samego i świata - jest racją pradecyzji (oraz trwającym przez całe życie „zyskiem”, jaki człowiek dzięki pradecyzji posiada i o który się troszczy). Skoro zaś w pradecyzji człowiek afirmuje racjonalność i autonomię własnej podmiotowości, to szczęście, które jest racją ich afirmacji, zobowiązuje do respektowania przede wszystkim moralności (jako praktycznej racjonalności w działaniach międzyosobowych), ale także do stosowania racjonalności w szerszym polu działań pozamoralnych. Jeżeli więc podmiot pogwałca normatywność moralną, to, praktycznie przecząc samemu sobie, traci eutymię - pozostają mu wtedy tylko akcydentalne, zawsze niedostateczne, składniki szczęścia. Tylko w takim sensie można zaakceptować znane hasło „warto być uczciwym” oraz jego odwrotność: „nie warto ignorować moralności”. W praktyce moralnej idea szczęścia przybiera charakter racji negatywnej: wzgląd na nią zabrania popełniania czynów niemoralnych - nakazuje nie naruszać normatywności (którą wszak samemu w pracedyzji nadało się ważność $)^{12}$. Respekt dla moralności jest w istocie respektem dla własnej woli bycia podmiotem - a odpowiednio i konsekwentnie kultywowana idea eutymii chroni przed bolesną abdykacją z podmiotowego statusu.

Drugim miejscem idei szczęścia, w którym ma ona charakter racji w uzasadnianiu normatywności, jest - jak już wspomniałem - sfera działań pozamoralnych. Tam, gdzie moje działania nie dosięgają innych podmiotów (w związku z czym nie jestem zobowiązany do kierowania się racjami moralnymi), normatywnością pozostaje dla mnie, by tak rzec, racjonalna ekonomia w wyborze akcydentalnych składników szczęścia. W tej sferze szczęście stanowi kryterium tzw. wysokości wartości: obiekt (przedmiot, zdarzenie lub działanie) jest tym bardziej wartościowy, im jego wkład w moje szczęście jest większy. Jeśli więc w sferze, o której tu mowa, racjonalną zasadą działania jest konserwacja i maksymalizacja szczęścia (bo innej być nie może), to zgodne z normatywnością są takie wybory,

\footnotetext{
${ }^{12} \mathrm{~W}$ sferze moralności respekt dla idei szczęścia jest, jak się zdaje, analogiczny do respektu wobec własnego sumienia, które także nie tyle „podpowiada” czyny pozytywne, co raczej wstrzymuje nas od czynów złych: „nie czyń zła, bo stracisz spokój sumienia”.
} 
które, po pierwsze, stopnia szczęścia nie obniżają, a po drugie, stopień ten, o ile jest to $\mathrm{w}$ danej sytuacji możliwe, podwyższają. Tylko takie wybory są więc w tej sferze racjonalne. Idea szczęścia ma tutaj charakter racji pozytywnej, gdyż jako powinność wskazuje aktywne podejmowanie takich działań, które bądź zabezpieczają trwanie aktualnego stopnia szczęścia, bądź stopień ten wzmagają. Jeśli w życiu pozamoralnym ktoś nie przestrzegałby zarysowanych tu reguł racjonalności praktycznej i miast podwyższać, obniżałby swymi działaniami stopień swojego szczęścia, to jego działania byłyby nie takie, jakie być powinny (niezgodne z normatywnością pozamoralną). Warto zastrzec, że pozytywność racji nakazującej maksymalizację szczęścia nie oznacza bynajmniej, że jej konsekwencją ma być jakiś nadmierny i ekspansywny aktywizm. Działaniami maksymalizującym i szczęście, obok zdobywania niezbędnych przedmiotów zewnętrznych, mogą, a nawet muszą, być również działania przeprowadzane na samym sobie, takie jak samokształcenie, ćwiczenie charakteru, aktywne pogłębianie samowiedzy czy wypracowywanie optymalnej postawy wobec życia, czyli tego typu działania, które zbiorczo można określić jako doskonalenie wewnętrzne.

Przedstawiając ideę szczęścia w roli „racji dla (konstytuującej normatywność) pradecyzji”, pozostaje na koniec wyjaśnić, w jakim sensie jest ona racją. Żeby uzyskała logiczną postać racji, trzeba, rzecz jasna, przedstawić ją w formie sądu. Jest on następujący: istnienie (tzn. uczestnictwo w rzeczywistości) daje mi (tzn. samookreślającemu się podmiotowi) szczęście (tzn. zadowolenie z dostępnej mi całości mojego istnienia). Ujmując to dla wygody w skrócie: istnienie mnie zadowala (w takim przynajmniej stopniu, że nie preferuję rezygnacji z niego). Otóż taki autorefleksyjny sąd jest - by tak rzec - myślową podstawą dla pierwszego sądu aksjologicznego, którego najprostsza postać jest taka: istnienie jest wartościowością (cennością). Ten treściowo najuboższy sąd można dokładniej rozwinąć dopiero po rozpoznaniu ontologicznych zależności między konkretami istniejącymi - a szczególnie idzie tu o zależność istnienia mnie jako podmiotu od (a) istnienia całej rzeczywistości oraz (b) istnienia innych podmiotów. Skoro bowiem nie mogę istnieć bez rzeczywistości, to nie mogę (na podstawie racji, iż moje istnienie daje mi zadowolenie) uznać wartości istnienia mojego bez uznania wartościowości istnienia świata. Podobnie dotyczy to istnienia innych podmiotów (co, jak wspominałem, funduje uznanie moralności). Najważniejsze jednak w tym pierwszym sądzie aksjologicznym (w sądzie: istnienie jest wartościowością) jest to, że stanowi 
on pierwszą przesłankę dla innych wnioskowań aksjologicznych oraz aksjologiczną rację dla wszystkich wartości.

Należy podkreślić, że relacja między sądem „istnienie mnie zadowala” a sądem (aksjologicznym) „istnienie jest wartościowością”, nie jest relacją wynikania logicznego. Z sądu deskryptywnego, że „X mnie zadowala”, nie wynika sąd aksjologiczny, że „X jest wartościowy”. Pierwszy sąd jest, jak to nazwałem, podstawą myślową sądu drugiego w nieco osobliwym sensie. Trzeba przede wszystkim zauważyć, że żaden z tych sądów nie dotyczy faktów przyrodniczych. Nawet stwierdzane w autorefleksji zadowolenie $z$ istnienia nie jest takim faktem, gdyż - jako wymagające syntetycznej „pracy” samowiedzy - nie jest niezależne od samoświadomości (nie występuje w przyrodzie). Warunkiem wystąpienia takiego zadowolenia jest wyższa forma świadomości: pojęciowa i refleksyjna, czyli taka, która umożliwia człowiekowi wolność od faktów. Pomimo że zadowolenie to nie jest faktem przyrody, sąd o nim jest jednak, jak się zdaje, deskryptywny - i dlatego sąd aksjologiczny nie jest od niego zależny w sensie logicznym.

Będąc, na mocy posiadania samoświadomości, bytem wolnym, podmiot zmuszony jest wobec istnienia oraz swojego zadowolenia $\mathrm{z}$ istnienia podjąć pierwotną decyzję, która dotyczy alternatywy: czy istnienie kontynuować, czy nie? Otóż wymieniony pierwszy sąd aksjologiczny, czyli sąd, że istnienie jest wartościowością, jest właśnie wytworem pradecyzji - jego źródłem nie są fakty, lecz wolność. $Z$ tego też powodu sformułowanie i podtrzymywanie tego sądu nie popada w błąd naturalistyczny. Znaczy to, że pomiędzy deskryptywnym sądem o zadowoleniu a aksjologicznym sądem afirmującym istnienie tkwi pradecyzja. Żeby jednak nie była ona aktem najzupełniej irracjonalnym (czymś w rodzaju rezultatu rzutu kostką), czyli żeby była decyzją sensu stricte, podmiot musi potrafić odpowiedzieć na pytanie, dlaczego ją podjął. I właśnie sąd o własnym zadowoleniu $\mathrm{z}$ istnienia jest taką - jedyną sensowną, jak twierdzę - odpowiedzią, która tę decyzję uwalnia od bezpodstawności.

Konstatację zadowolenia $\mathrm{z}$ istnienia można zatem uznać za rację pradecyzji nie dlatego, że treść pradecyzji z konstatcji tej logicznie wynika, lecz dlatego, że decyzja przeciwna nie posiada uzasadnienia. Nie istnieje bowiem racja, dla której wobec konstatacji o zadowoleniu $\mathrm{z}$ istnienia - nie miałbym siłą decyzji uznać istnienia za wartościowość. Innymi słowy, skoro istnienie mnie zadowala, to mojej decyzji o kontynuowaniu istnienia (czyli decyzji dekretującej wartościowość ist- 
nienia) - przy braku racji przeciwnej - nie można zarzucić niesłuszności (nieracjonalności). Właśnie w takim, i tylko w takim, sensie szczęście jest racją pradecyzji.

Reguła, wedle której zadowolenie jest wystarczającą podstawą dla decyzji o uznaniu przedmiotu tego zadowolenia za wartościowy jest regułą obowiązującą w całym obszarze rozumowania praktycznego, z tym jednak ważnym zastrzeżeniem, iż jest ona słuszna wyłącznie wtedy, gdy nie istnieją przeciwne racje praktyczne, zabraniające realizacji poszczególnego zadowolenia czy pragnienia. Zazwyczaj takie kontrracje istnieją - i dlatego w codziennej, zróżnicowanej sferze życia praktycznego niesłuszna jest reguła orzekająca, iż każdy przedmiot zadowolenia jest wartościowy. W istocie tylko ten przedmiot zadowolenia jest wartościowy, któremu nie przeczy racjonalność praktyczna, a to znaczy taki, co do którego decyzja o jego osiąganiu nie znajduje racji przeciwnej. Konieczność opierania racji praktycznych na pochodzących spoza rozumu zadowoleniach czy pragnieniach bierze się stąd, że racjonalność praktyczna jest czysto formalna, w związku z czym nie jest zdolna do wskazania aksjologicznej treści. I chociaż nie może być wartościowe coś, co nie uzyskuje legitymizacji przez tę racjonalność, to jednak ona sama musi swoje treściowe przesłanki czerpać spoza siebie - jej rolą jest eliminowanie sprzeczności wśród przedmiotów faktycznych pragnień oraz wykluczanie spośród nich przedmiotów fikcyjnych (realnie niemożliwych). To wszystko oznacza, że pragnienie, przeciwko któremu rozum nie znajduje żadnej kontracji, samo staje się racją praktyczną.

Otóż takim właśnie pragnieniem - i to absolutnie podstawowym - jest dążenie do utrwalenia i maksymalizacji szczęścia. Ponieważ dla tego podstawowego dążenia nie istnieją racje przeciwne, toteż ono samo jest racją: najpierw racją dla pradecyzji, a następnie, za pośrednictwem treści pradecyzji (w sposób, który wcześniej scharakteryzowałem), racją dla respektowania całej normatywności. 


\section{Bibliografia}

Arystoteles. Etyka Nikomachejska. Tłum. Daniela Gromska. Warszawa: PWN, 2012.

Biblia Tysiąclecia.

Brożek, Anna, Bartosz Brożek, Jerzy Stelmach. Fenomen normatywności. Kraków: Copernicus Center Press, 2013.

Duchliński, Piotr. „Normatywność - jej źródła i sposoby jej badania. Analiza metateoretyczna”. W: Piotr Duchliński, Andrzej Kobyliński, Ryszard Moń, Ewa Podrez. O normatywności w etyce, 17-61. Kraków: Wydawnictwo WAM, 2015.

Heidegger, Martin. Bycie i czas. Tłum. Bogdan Baran. Warszawa: PWN, 1994.

Ingarden, Roman. Wykłady z etyki. Warszawa: PWN, 1989.

Kant Immanuel. Krytyka czystego rozumu. Tłum. Roman Ingarden. Warszawa: PWN, 1986.

Kant Immanuel. Krytyka praktycznego rozumu. Tłum. Jerzy Gałecki. Warszawa: PWN, 1984.

Kant, Immanuel. Uzasadnienie metafizyki moralności. Tłum. Mścisław Wartenberg. Warszawa: PWN, 1984.

Kopciuch, Leszek. Wolność a wartości. Max Scheler, Nicolai Hartmann, Dietrich von Hildebrand, Hans Reiner. Lublin: Wydawnictwo UMCS, 2010.

Korsgaard, Christine Marion. Sources of Normativity. New York: Cambridge University Press, 1996.

Kramer, Hans. Etyka integralna. Tłum. Marcin Poręba. Toruń: Wydawnictwo Rolewski, 2004.

Nagel, Thomas. Widok znikąd. Tłum. Cezary Cieślińsk. Warszawa: Fundacja Aletheia, 1997.

Niemczuk, Andrzej. „Aksjologiczne uzasadnienie etyki”. W: Andrzej Niemczuk. Filozofia praktyczna. Studia i szkice, 239-270. Lublin: Wydawnictwo UMCS, 2016.

Niemczuk, Andrzej. „Błąd teoretyzmu w aksjologii”. W: Andrzej Niemczuk. Filozofia praktyczna. Studia i szkice, 13-45. Lublin: Wydawnictwo UMCS, 2016.

Niemczuk, Andrzej. Filozofia dobra przed powstaniem aksjologii. Lublin: Wydawnictwo UMCS, 1994.

Niemczuk, Andrzej. „Kolista struktura praktyki. Rozważania metapraktyczne”. W: Andrzej Niemczuk. Filozofia praktyczna. Studia i szkice, 125-147. Lublin: Wydawnictwo UMCS, 2016.

Niemczuk, Andrzej. „O poznaniu wartości”. W: Andrzej Niemczuk. Filozofia praktyczna. Studia $i$ szkice, 71-74. Lublin: Wydawnictwo UMCS, 2016.

Niemczuk, Andrzej. „Practical Rationality - its Nature and Operation”. Studia Humana 8, nr 2 (2019): 55-68.

Niemczuk, Andrzej. Traktat o złu. Lublin: Wydawnictwo UMCS, 2013.

Prichard, Harold Arthur. „Does Moral Philosphy Rest on a Mistake?”. Mind 1912, nr 21: 487499.

Rawls, John. Teoria sprawiedliwości. Tłum. Maciej Panufnik, Jarosław Pasek, Adam Romaniuk. Warszawa: PWN, 1994. 
Spaemann, Robert. Szczęście a życzliwość. Esej o etyce. Tłum. Jarosław Merecki. Lublin: Redakcja Wydawnictw KUL, 1997.

Spinoza, Baruch. Etyka w porządku geometrycznym dowiedziona. Tłum. Ignacy Myślicki. Warszawa: PWN, 1954.

Stoiński, Andrzej. „Wybrane wątki krytyki utylitaryzmu”. Humanistyka i Przyrodoznawstwo 2014, nr 20: 369-383.

Szubert, Tomasz. Szczeście i jego determinanty ekonomiczne. Warszawa: Wydawnictwo CeDeWu, 2019.

Tatarkiewicz, Władysław. O szczęściu. Warszawa: PWN, 1985.

Tugendhat, Ernst. Wykłady o etyce. Tłum. Janusz Sidorek. Warszawa: Oficyna Naukowa, 2004. White, Nicholas. Filozofia szczęścia. Od Platona do Skinnera. Tłum. Marek Chojnacki. Kraków: Wydawnictwo WAM, 2008.

Williams Bernard. „Osoby, charakter i moralność”. Tłum. Tadeusz Baszniak. W: Bernard Williams. Ile wolności powinna mieć wola? I inne eseje z filozofii moralnej, 239-244. Warszawa: Fundacja Aletheia, 1999.

\section{Summary}

\section{Happiness in the Structure of Normativity (part II - Happiness)}

The main presumption in ethics before Kant was that in pursuit of his activities, man should strive first and foremost at making himself happy. Subsequently to Kant's argument contravening the notion of man's duty to promote one's own happiness and his theory of naturalistic fallacy, contemporary theories of normativity (except utilitarianism) are based on the premise of separating normativity from happiness. Arguments are presented in this paper in support of critical statements that (a), without reference to happiness, normativity cannot be satisfactorily explained nor justified and (b), that the utilitarian concept of happiness cannot justify normativity. The author gives an outline of the normativity structure and ponders why normativity should be respected. He presents a concept of happiness which does not exclude normativity but provides the necessary justification for it. After identifying the concept of happiness, its core is described as euthymia, understood as stable satisfaction with being a subject. The author concludes that happiness and normativity are complimentary.

Keywords: normativity, happiness, practical subject, practical philosophy 


\section{Zusammenfassung}

\section{Das Glück in der Struktur der Normativität (Teil II - das Glück)}

Die vorkantianische Ethik war auf dem Schema aufgebaut, dem zufolge der Mensch in seiner praktischen Tätigkeit das machen sollte, was ihn glücklich macht. Der Streit betraf nur die Natur des Glücks und die Natur des Menschen. Die Kantianische Beanstandung der Pflichtbegründung mittels der Rückgriffe auf das Glück und die Theorie des naturalistischen Fehlers verursachten, dass sich die gegenwärtigen Theorien der Normativität (abgesehen von dem Utilitarismus) auf dem Grundsatz der Trennung von Normativität und Glück stützen, was die Verdrängung der Glücksproblematik aus der praktischen Philosophie nach sich zieht. Den Ausgangspunkt des Beitrags bildet die Argumentation zugunsten folgender kritischer Behauptungen: a) die Normativität kann ohne den Rückgriff auf das Glück weder ausreichend erklärt noch begründet werden; b) das utilitaristische Glückskonzept eignet sich nicht zur Begründung der Normativität. Der erste Teil des Artikels wird durch den Umriss der Normativitätsstruktur abgerundet, wobei eine Antwort auf die Frage: Warum soll ich die Normativität respektieren? vorgeschlagen wird. Der zweite Teil des Artikels präsentiert ein solches Glückskonzept, das die Normativität nicht ausschließt, sondern für sie eine unentbehrliche Begründung bildet. Nach der Identifizierung des Designats des Glücksbegriffs wird sein Kern in Form von Euthymie charakterisiert, die als eine stabile Zufriedenheit mit der Tatsache des Subjektseins verstanden wird. Das Ganze schließt die Argumentation ab, die die Komplementarität von Glück und Normativität zeigt.

Schlüsselworte: Normativität, Glück, praktisches Subjekt, praktische Philosophie

Information about Author:

ANDRZEJ NIEMCZUK, habilitated doctor, associate professor, Institute of Philosophy, Faculty of Sociology and History, University of Rzeszów; address for correspondence: al. T. Rejtana 16 C, 35959 Rzeszów, Poland; e-mail: aniemczuk@ur.edu.pl

(cc) BY-NC-ND 